\title{
Cough Treatment Options in Children with Acute Respiratory Infections
}

\section{BM Blokhin*, IP Lobushkova, AS Suyundukova and AD Prokhorova}

Department of Outpatient and Emergency Paediatrics, Pirogov Russian National Research Medical University of the Ministry of Health of the Russian Federation,

Moscow, Russia

*Corresponding Author: BM Blokhin, Department of Outpatient and Emergency Paediatrics, Pirogov Russian National Research Medical University of the Ministry of Health of the Russian Federation, Moscow, Russia.
Received: May 24, 2021

Published: June 30, 2021

(C) All rights are reserved by BM Blokhin., et al.

\section{Abstract}

Introduction: The article contains the results of a non-interventional, multicentre, prospective, observational, non-randomized clinical trial evaluating the efficiency and safety of Stodal drug product in children aged 2 to 7 years old with cough caused by acute respiratory infection (ARI).

Objective of the Research: To assess therapeutic efficiency and safety of Stodal drug product in children treated for cough caused by mild to moderate acute respiratory infections.

Materials and Methods: The study included 1000 children aged 2 to 7 years old with cough caused by mild to moderate ARI. The study was conducted in 23 medical institutions based in Moscow and the Moscow region. The study participants were stratified by age into 2 groups: Group 1 included children aged 2 to 4 years old; Group 2 included children aged 4 to 7 years old. Stodal clinical efficiency was evaluated based on the time course of cough severity in the daytime and at night, parents'/adoptive parents' satisfaction with the treatment and the treatment safety. Treatment duration was 7 days.

Results: In both groups, on the $7^{\text {th }}$ day of therapy, treatment with Stodal resulted in a statistically significant decrease in cough severity: in Group 1, cough severity decreased by 1.51 (from 2.16 to 0.65 ; p < 0,001); in Group 2 it decreased by 1.57 (from 2.25 to $0.68 ; \mathrm{p}<0.001)$. Treatment efficiency was not age-dependent and was similar in both groups ( $\mathrm{p}=0.158)$. In total population cough severity in the daytime statistically significantly decreased by 1.53 (from 2.2 on the $1^{\text {st }}$ day of treatment to 0.67 points on the $7^{\text {th }}$ day of treatment, $\mathrm{p}<0.001$ ). In $35 \%$ of patients cough completely resolved (cough severity decreased to 0 points), and in $63 \%$ it became clinically insignificant (cough severity was 1 point). These children recovered and were allowed to attend organized groups. In Group 1 , nocturnal cough severity statistically significantly decreased by 1.16 (from 1.64 to $0.48, \mathrm{p}<0.001$ ); in Group 2 it decreased by 1.25 (from 1.71 to $0.46, \mathrm{p}<0.001) .951(95,1 \%)$ parents/adoptive parents positively rated cough treatment and scored it using satisfaction rating scale as 4 and 5 points.

Conclusion: The study demonstrated efficiency and safety of Stodal drug product when used for cough treatment in children aged 2 to 7 years old with mild to moderate ARI, which allows to recommend Stodal to be included in treatment regimens beginning from the first days of the disease.

Keywords: Children Aged 2 to 7 Years Old; Acute Respiratory Infection; Cough; Cough Severity; Stodal 


\section{Introduction}

Acute respiratory infections (ARI) take the leading place in the structure of infectious diseases in children. According to Rospotrebnadzor data, in 2018, 20.4 million cases of ARI were reported in children aged $0-14$ years, which is 80.8 thousand cases per 100 thousand of child population [1].

In children ARIs are accompanied with cough in $90 \%$ of cases. Moreover, in $32.1 \%$ of children with infectious respiratory tract diseases, the duration of cough is 3 weeks or more [2,3].

The severity and the duration of cough depend on the pathological process aetiology. One of the classifications contains the variations of cough depending on its duration: acute cough lasting up to three weeks, sub-acute or prolonged cough lasting 3 to 6 weeks and chronic cough lasting more than 6 weeks [4]. Up to $90 \%$ cases of cough syndrome are associated with acute infectious respiratory tract pathology of viral aetiology, and the remaining $10 \%$ are bacterial infections, allergic pathology, foreign bodies, congenital abnormalities, post-infectious cough [4,5]. ARI is a self-limiting disease that usually resolves on its own within 2 weeks [6]. However, cough can persist even after the elimination of the infectious factor [7]. Cough and mucociliary clearance are the most important respiratory tract's defensive mechanisms [8,9]. Normally, mucus traps inhaled particles, and due to mucociliary clearance, the mucus produced is constantly eliminated, which minimizes the contact of external agents with the respiratory tract (RT) epithelium [10]. Cough helps to remove excess secretions and foreign particles from the mucous membrane of the respiratory tract. During respiratory infections, whether they are of viral or bacterial aetiology, the effectiveness of mucociliary clearance is impaired. One of the possible explanations is that the combined action of pathogens and the release of inflammatory mediators significantly suppress mucociliary clearance, both by increasing the production of viscous mucus and by reducing the efficiency of beating of cilia of the ciliated epithelium [11]. Progressive accumulation of mucus and the presence of inflammatory mediators trigger the cough reflex [12].

At the first stage of the "invasion" of infection into the RT mucous membrane inflammation develops (with the increase in expression of inflammatory mediators such as prostaglandins, leukotrienes, cytokines, histamine and free radicals) $[9,10]$. The main manifestations of the inflammatory reaction are edema, hyperse- cretion, bronchospasm, impaired mucociliary transport and, as a consequence, the onset of cough [9-11].

In young children, active bronchial motility is insufficient due to weak muscle development and immaturity of the ciliated epithelium. They have a poorly developed cough reflex: incomplete myelination of the vagus nerve and immaturity of the respiratory muscles cause weakness of the cough impulse [12-14]. The presence of a large number of mucous glands in the trachea and bronchi in children leads to increased production of mucus, although the drainage function is poorly developed [12]. Therefore, it's vital to begin treating cough during ARI at an early stage of the disease, when inflammation dominates in the pathogenesis. Acute treatment of cough at the onset of the disease helps to avoid further prescription of mucolytic drug products and reduces the risk of complications. Unreasonable use of mucolytics can lead to profuse sputum production up to the development of respiratory tract congestion, which is especially important for young children [3].

On early stages of cough, antitussive drugs with central action which inhibit the cough reflex and the cough centre in the brain are often prescribed. These drugs do not affect the pathogenesis of cough. Suppression of the cough reflex prevents the evacuation of mucus and infectious agents from RT, which can cause prolongation of cough and its further progression in the form of bronchitis and pneumonia $[3,13]$.

When choosing a drug product for cough treatment in children, it is necessary to take into account its safety in the paediatric population. It is recommended to use drug products that simultaneously affect the key causes of cough, in particular inflammation of the respiratory tract mucosa [15]. One of such drug products is Stodal.

Stodal is a drug product that contains a number of natural active substances that have a complex anti-inflammatory, antitussive and antimicrobial action [16].

The efficacy of Stodal in the treatment of cough has been demonstrated in many clinical studies.

A double-blind, randomized, placebo-controlled study conducted in Italy in 2013, demonstrated the efficacy and rapid onset of action of Stodal syrup compared to placebo when assessing the effect on cough caused by uncomplicated RT infections [16]. 
N.A. Geppe., et al. conducted a study of Stodal vs. ambroxol/carbocystein in the treatment of children with cough associated with ARI. The therapeutic effect of the treatment using Stodal syrup was more pronounced from the first day of treatment and by the $7^{\text {th }}$ day the measured parameters were similar to the control group treated with mucolytics, or even better. In the group of patients treated with Stodal, cough resolved in $98 \%$ of cases by the $7^{\text {th }}$ day of treatment. In the control group, after 7 days of therapy, a paroxysmal dry cough still persisted in $10 \%$ of patients, and $20 \%$ of children still had residual cough [17]. The benefits of Stodal are related to its complex anti-inflammatory, antitussive and antimicrobial action [16].

In a study conducted by A.L. Zaplatnikov., et al. the clinical efficacy of Stodal was compared to the efficacy of a codeine-containing drug product in 61 preschool children with frequent, intense, unproductive cough during ARI. It was shown that in the main group (treated with Stodal) the night cough resolved by the end of the $5^{\text {th }}$ day of treatment compared to the control group (treated with a codeine-containing drug product) in which cough symptoms resolved only on the $7^{\text {th }}$ day of the treatment. A faster reduction of nocturnal coughing episodes made it possible to normalize sleep in children taking Stodal faster [18].

\section{Materials and Methods}

During this non-interventional, multicentre, prospective, observational, nonrandomized clinical trial, 2 groups of patients of different ages were enrolled, which were analysed both separately and altogether. The clinical study was conducted in 23 research centres based in Moscow and the Moscow region from 10/23/2019 to $12 / 29 / 2019$ with the purpose to assess the therapeutic efficiency and tolerability of Stodal drug product in the treatment of cough in children aged 2 to 7 years with ARI of mild to moderate severity accompanied by cough. Potential study participants were selected from the children who sought medical help due to the current ARI. The choice of the treatment method and all physical examination were carried out by the paediatrician evaluating the patient, in accordance with the practice accepted in the medical institution. The study included outpatients whose cough duration at the time of screening did not exceed 3 days. All parents/adoptive parents of patients signed an informed consent for the participation of their children in the clinical trial.
A total of 1,079 patients underwent screening. During the study, 79 patients discontinued the study due to various reasons. Thus, 1000 children correctly used the study drug, completely passed the screening and completed the study, having passed all the procedures stipulated by the protocol. In total, 1000 children completed the study: 518 boys (51.8\%, 95\% CI: 48.7-54.9\%) and 482 girls (48.2\%, 95\% CI: 45.2-51.3\%).

The study participants were stratified by age into 2 groups: Group 1: children aged 2 to 4 years - 500 patients; Group 2: children aged 4 ( +1 day) to 7 years -500 patients.

There were no statistically significant differences between the groups by gender $\left(\mathrm{p}<0.05, \mathrm{x}^{2}\right)$ (Figure 1).

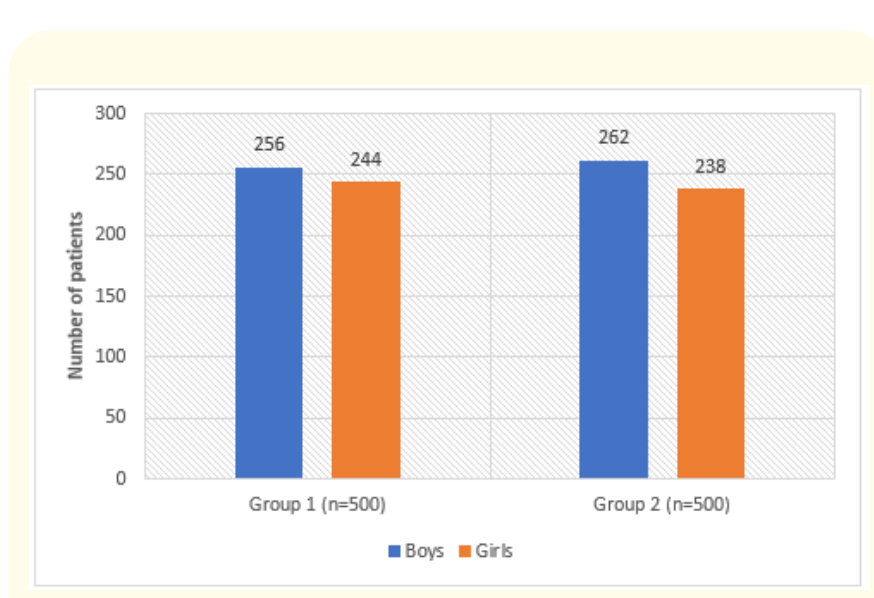

Figure 1: Patients distribution according to gender.

Demographic and anthropometric data of children included in the study are presented in Table 1 . It was supposed that there would not be any significant differences in body weight, height and age between groups, and therefore no formal statistical comparison of these parameters was carried out.

To collect data an electronic information collection system was used with some restrictions related to the number of patients included in the study. This was done to ensure that equal numbers of children (500) were enrolled into each group. 
The mean daily duration of cough at baseline is presented in Table 2. Children in both groups were comparable in terms of duration of the disease and the presence of cough.

Stodal was administered in accordance with the official prescribing information: $5 \mathrm{ml}$ using the provided pre-measured cup, 5 times per day, 15 minutes before or 1 hour after a meal. Treatment duration was 7 days.

All children started taking Stodal during the first 3 days since the onset of the disease and the onset of cough. So, on the first day of the disease Stodal was prescribed to $39.4 \%$ (95\% CI: 36.4-42.4\%), on the Day 2 it was prescribed to $48.8 \%$ (95\% CI: 45.7-51.9\%) and on Day 3 it was prescribed to $11.8 \%$ (95\% CI: 9,8-13,8\%).

Since this study was observational, all therapeutic and diagnostic procedures were prescribed at the discretion of the pediatrician, depending on the condition of the child and in accordance with routine practice. The doctor made an independent decision to prescribe Stodal in addition to ARI therapy or to modify the existing treatment regimen.

During the study there were three visits of the researching physician (pediatrician): on Day 1, Day 3 and Day $8(+2)$ of the study. Patients began to take the study drug on Day 1 and finished it on Day 7. Parents/adoptive parents performed daily assessments of cough and recorded the results in the patient's diary every day throughout the study.

The physical examination performed during the study did not reveal any clinically significant deviations, except for those associated with the current ARI, in all the patients. The main disease manifestation included daytime and nocturnal cough, weakness, nasal congestion, rhinorrhoea, sore throat, increased body temperature, etc.

The scoring of the cough severity in the daytime and at night was carried out in accordance with the following scale $[19,20]$ :

0 points = no symptoms (no cough);

1 point = symptoms (cough) are mild; short-term, and does not affect the child's lifestyle or behaviour;

2 points = severe symptoms (cough); observed during the day, has a moderate effect on the normal lifestyle and behaviour of the child;
3 Points = symptoms (cough) are very severe: severe cough is observed during the day, which worsens the child's condition and has a significant impact on his behaviour.

Parents/adoptive parents' satisfaction with the treatment of cough with Stodal was assessed using a 5-point Likert scale with adaptation [21], where:

1 point = not satisfied with the treatment;

2 points = rather not satisfied with the treatment;

3 points = not sure;

4 points = rather satisfied with the treatment;

5 points = completely satisfied with the treatment;

\begin{tabular}{|l|c|c|c|}
\hline \multicolumn{1}{|c|}{ Groups } & Age, y.o. & Height, cm & $\begin{array}{c}\text { Body } \\
\text { weight, kg }\end{array}$ \\
\hline Group 1 $(\mathrm{n}=500)$ & $3.1 \pm 0.6$ & $97.3 \pm 8.5$ & $14.8 \pm 2.6$ \\
\hline Group 2 (n=500) & $5.5 \pm 0.9$ & $112.2 \pm 9.4$ & $19.7 \pm 4.2$ \\
\hline All patients ( $\mathrm{n}=1000)$ & $4.3 \pm 1.4$ & $\begin{array}{c}104.8 \pm \\
11.6\end{array}$ & $17.2 \pm 4.3$ \\
\hline
\end{tabular}

Table 1: Baseline demographic and anthropometric parameters of patients included in the study (Mean \pm SD).

\begin{tabular}{|c|c|c|c|c|}
\hline \multirow{2}{*}{ Groups } & & \multicolumn{3}{|c|}{ Duration of cough, } \\
& & \multicolumn{3}{|c|}{ Days } \\
\cline { 2 - 5 } & & $\mathbf{1}$ & $\mathbf{2}$ & $\mathbf{3}$ \\
\hline \multirow{2}{*}{ Group 1 (n=500) } & $\mathrm{n}$ & 207 & 236 & 57 \\
\cline { 2 - 5 } & $\%$ & 41.4 & 47.2 & 11.4 \\
\hline \multirow{2}{*}{ Group 2 (n = 500) } & $\mathrm{n}$ & 187 & 252 & 61 \\
\cline { 2 - 5 } & $\%$ & 37.4 & 50.4 & 12.2 \\
\hline \multirow{2}{*}{ All patients (n=1000) } & $\mathrm{n}$ & 394 & 488 & 118 \\
\cline { 2 - 5 } & $\%$ & 39.4 & 48.8 & 11.8 \\
\hline
\end{tabular}

Table 2: Duration of cough at screening.

\section{Processing of the data}

During the study, patients' parents had to fill the treatment diaries. After the study was completed the diaries were checked for accuracy and completeness, then the data from the diaries were entered into the system of electronic case record form (eCRF) to prepare a single database for statistical analysis. 


\section{Statistical methods}

The data obtained were analysed using the statistical software IBMSPSS 17.0. Numeric data (such as, for example, age, scores (points)) obtained during the study were tested for normality of distribution using the Kolmogorov-Smirnov test, then the variables corresponding to the normal distribution were described using the number of patients, the arithmetic mean, and the standard deviation. Qualitative variables were described by absolute values and relative frequencies (percentages) and 95\% CI. For the analysis of numeric data, the ANOVA statistical method (Repeated measuresANalysis Of Variance) with repeated measurements was used to assess the significance of the time-course in total population for several days. In the presence of statistically significant differences (in the time-course), post-hoc comparisons between days were made using Student's t-test for paired samples, taking into account multiple comparisons. Qualitative data were analysed using the $\chi 2$-test; in case of its inapplicability, Fisher's exact test was used. In accordance with the practice generally accepted in biomedical researches, a value of $5 \%$ was used as the maximum allowable limit of type I error (the probability of a false-positive result). The sample size was not pre-calculated.

\section{Results and Discussion}

The study included 1079 patients, 57 of which were excluded at screening. 22 patients discontinued during the study (14 children in Group 1 and 8 children in Group 2). The main reasons for discontinuation from the study included withdrawal of consent and non-compliance with the drug product intake regimen. 1000 patients (500 people in each group) completed the study. They took the study drug product correctly and completed the course of treatment. The study demonstrated the effectiveness of Stodal in the treatment of cough during ARI, which is confirmed by a statistically significant decrease in the mean score of the cough severity in the daytime by the $7^{\text {th }}$ day of therapy in total population and in each group, as well as by a statistically significant change in the cough severity on the $7^{\text {th }}$ day of treatment compared to the $1^{\text {st }}$ day in total population and in each group (Table 3, Figure 2 and 3). In Group 1 the severity of cough in the daytime statistically significantly decreased by 1.51: from 2.16 on the first day of treatment to 0.65 on the $7^{\text {th }}$ day of treatment $(\mathrm{p}<0,001)$. In Group 2 the severity of cough in the daytime statistically significantly decreased by 1.57: from 2.25 on the first day of treatment to 0.68 on the $7^{\text {th }}$ day of treatment $(p<0,001)$. There was no statistically significant dif- ference in the decrease in the severity of daytime cough between the groups $(\mathrm{p}=0.158)$.

In total population the severity of cough in the daytime statistically significantly decreased by 1.53 : from 2.2 on the first day of

\begin{tabular}{|l|c|c|c|c|c|c|c|c|}
\hline \multirow{2}{*}{ Groups } & \multicolumn{7}{|c|}{ Days of treatment } \\
\cline { 3 - 9 } & & $\mathbf{1}$ & $\mathbf{2}$ & $\mathbf{3}$ & $\mathbf{4}$ & $\mathbf{5}$ & $\mathbf{6}$ & $\mathbf{7}$ \\
\hline $\begin{array}{l}\text { Group } 1 \\
(\mathrm{n}= \\
500)\end{array}$ & Mean, points & 2,16 & 2,14 & 1,89 & 1,64 & 1,31 & 1,05 & 0,65 \\
\cline { 2 - 9 } & SD & 0,71 & 0,69 & 0,63 & 0,57 & 0,54 & 0,44 & 0,51 \\
\hline $\begin{array}{l}\text { Group 2 } \\
(\mathrm{n}= \\
500)\end{array}$ & Mean, points & 2,25 & 2,21 & 1,91 & 1,66 & 1,36 & 1,04 & 0,68 \\
\cline { 2 - 9 } & SD & 0,67 & 0,65 & 0,62 & 0,53 & 0,54 & 0,45 & 0,49 \\
\hline $\begin{array}{l}\text { All } \\
\text { patients } \\
(\mathrm{n}= \\
1000)\end{array}$ & Mean, points & 2,20 & 2,18 & 1,90 & 1,65 & 1,33 & 1,04 & 0,67 \\
\cline { 2 - 8 } & SD & 0,69 & 0,67 & 0,62 & 0,55 & 0,54 & 0,45 & 0,50 \\
\hline
\end{tabular}

Table 3: The time-course of cough severity.

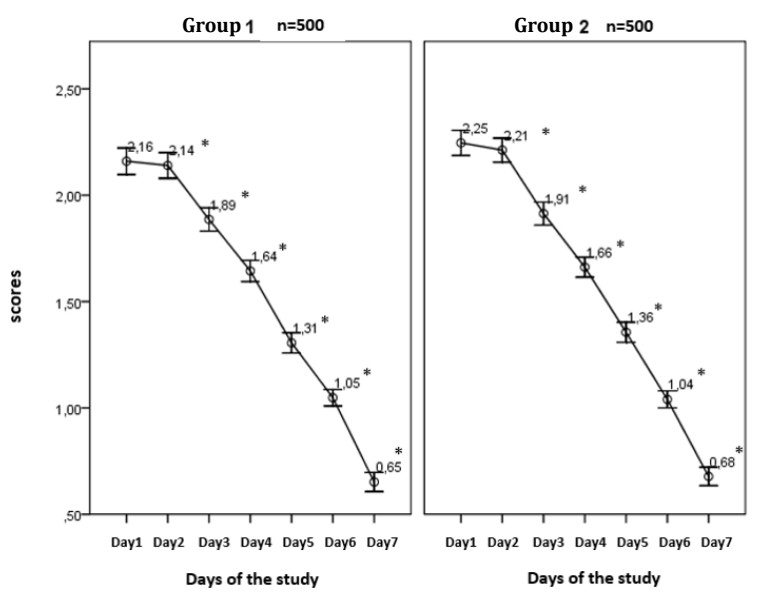

Figure 2: Dynamics of daytime cough intensity by groups.

$$
{ }^{*} \mathrm{p}<0.001 \text { vs. Day } 1 .
$$

The large sample size provided statistical significance of the change of cough intensity already on the $2^{\text {nd }}$ day of treatment in both groups $(p<0.001)$. A clinically significant decrease in the severity of daytime cough (more than 1 point) occurred by the $6^{\text {th }}$ day of therapy. 


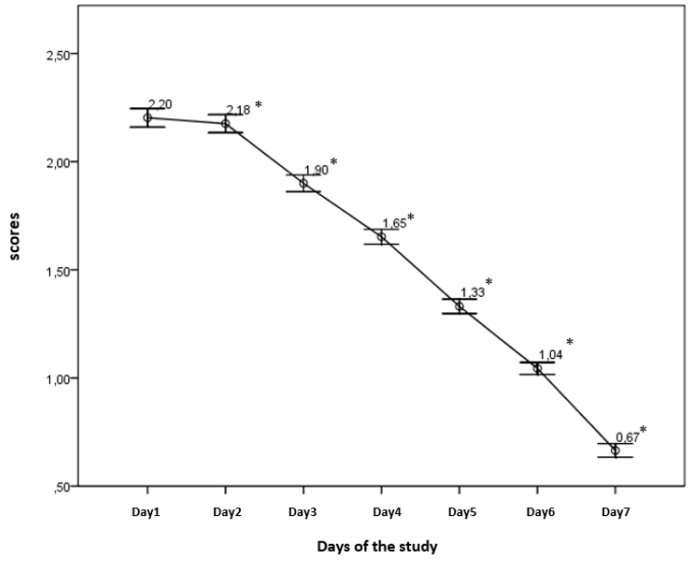

Figure 3: Dynamics of daytime cough intensity

(all patients $n=1000$ ).

$* \mathrm{p}<0.001$ vs. Day 1.

The large sample size provided statistical significance of the change of the cough intensity already on the $2^{\text {nd }}$ day of treatment $(\mathrm{p}<0.001)$. A clinically significant decrease in the severity of daytime cough (more than 1 point) occurred by the $6^{\text {th }}$ day of the therapy.

treatment to 0.67 on the $7^{\text {th }}$ day of treatment $(\mathrm{p}<0.001)$. The severity of cough decreased 3.3-fold.

During the study the statistical significance of the time-course of cough severity was demonstrated in both groups as early as on the $2^{\text {nd }}$ day of treatment $(\mathrm{p}<0.001)$. A clinically significant decrease in the daytime cough severity (of more than 1 point) occurred by the $6^{\text {th }}$ day of treatment.

Thus, Stodal provided a statistically significant decrease in the mean score of the daytime cough severity by the $7^{\text {th }}$ day of treatment, both in total population and in each age group.

The number of patients whose cough completely resolved or became clinically insignificant by the end of the study was $98 \%$ (95\% CI: 97,1-98,9\%). Those patients recovered.

According to the results of nocturnal cough severity assessment, the following statistically significant results were obtained (Table 4, Figure 4 and 5):
112

\begin{tabular}{|l|c|c|c|c|c|c|c|c|}
\hline \multirow{2}{*}{ Groups } & \multicolumn{7}{|c|}{ Days of treatment } \\
\cline { 3 - 9 } \multicolumn{2}{|c|}{} & $\mathbf{1}$ & $\mathbf{2}$ & $\mathbf{3}$ & $\mathbf{4}$ & $\mathbf{5}$ & $\mathbf{6}$ & $\mathbf{7}$ \\
\hline $\begin{array}{l}\text { Group 1 } \\
(\mathrm{n}=500)\end{array}$ & Mean, points & 1,64 & 1,58 & 1,19 & 1,02 & 0,84 & 0,64 & 0,48 \\
\cline { 2 - 9 } & SD & 0,91 & 0,85 & 0,75 & 0,70 & 0,68 & 0,68 & 0,69 \\
\hline $\begin{array}{l}\text { Group 2 } \\
(\mathrm{n}=500)\end{array}$ & Mean, points & 1,71 & 1,61 & 1,19 & 1,02 & 0,81 & 0,62 & 0,46 \\
\cline { 2 - 9 } & SD & 0,91 & 0,88 & 0,73 & 0,68 & 0,63 & 0,64 & 0,64 \\
\hline $\begin{array}{l}\text { All } \\
\text { patients } \\
(\mathrm{n}= \\
1000)\end{array}$ & Mean, points & 1,68 & 1,60 & 1,19 & 1,02 & 0,82 & 0,63 & 0,47 \\
\cline { 2 - 9 } & SD & 0,91 & 0,86 & 0,74 & 0,69 & 0,65 & 0,66 & 0,66 \\
\hline
\end{tabular}

Table 4: Nocturnal cough severity time-course

- In Group 1 the severity of nocturnal cough decreased by 1.16: from 1.64 on the first day of treatment to 0.48 on the $7^{\text {th }}$ day of treatment $(\mathrm{p}<0.001)$;

- In Group 2 the severity of nocturnal cough decreased by 1.25: from 1.71 on the first day of treatment to 0.46 on the $7^{\text {th }}$ day of treatment $(\mathrm{p}<0.001)$;

In total population the severity of nocturnal cough decreased by 1.21: from 1.68 on the first day of treatment to 0.47 on the $7^{\text {th }}$ day of treatment $(\mathrm{p}<0.001)$. The severity of nocturnal cough decreased 3.6-fold. Table 4 and Figure 4 and 5 demonstrate a statistically significant decrease of the score of the nocturnal cough severity in each of the groups and in the total population.

During the study the statistical significance of the time-course of nocturnal cough severity was demonstrated in both groups as early as on the $2^{\text {nd }}$ day of treatment $(\mathrm{p}<0.001)$. A clinically significant decrease in the nocturnal cough severity (of more than 1 point) occurred by the $6^{\text {th }}$ day of treatment.

There was no statistically significant difference in the decrease in the severity of nocturnal cough between the groups $(p=0.134)$.

During the study the statistical significance of the changes obtained was demonstrated as early as on the $2^{\text {nd }}$ day of treatment $(p$ $<0.001$ ). A clinically significant decrease in the nocturnal cough severity (of more than 1 point) occurred by the $6^{\text {th }}$ day of treatment. 
The majority of parents assessed the time-course of cough severity by the $3^{\text {rd }}$ day and by the end of the treatment period as positive. Tables 5 and 6 show subjective assessments of cough treatment by Stodal performed by parents/adoptive parents by the $3^{\text {rd }}$ and $7^{\text {th }}$ days of treatment.

In total 622 (62.2\%, 95\% CI: 59.2-65.2\%) parents/adoptive parents were completely satisfied with the treatment (scores of 5 or more points), 329 (32.9\%, 95\% CI: 30-35.8\%) parents/adoptive parents were mostly satisfied with the treatment (score of 4). This, 951 (95.1\%, 95\% CI: 93.8-96.4\%) parents/adoptive parents positively rated cough treatment with Stodal and graded it as 4 or 5 points (Table 7 ).

\section{Adverse events}

Stodal was well-tolerated by patients; adverse events (AE) were rare and mild. During the study 5 AEs were reported $(0.5 \%, 95 \%$ CI: $0.1-0.9 \%$ ) in both age groups (3 AEs in Group 1 and 2 AEs in Group 2). In Group 1 the following AEs were reported: moderate eosinophilia (increased levels of eosinophils of up to 7\%), catarrhal otitis media and an allergic reaction in the form of a skin rash. In Group 2 the following AEs were reported: increased levels of eosinophils of up to $8 \%$ and otitis media. According to researching physicians' assessment all AEs did not have any casual relationship with Stodal treatment according to WHO rating scale [22], did not require the cancellation or dose reduction of the studied drug product. Serious AEs were not reported. One of the limitation of the study could be related to its non-randomized nature. This limitation is significantly levelled down by the fact that this study is noninterventional, which brings it as close as possible to the settings of routine medical practice and, therefore, ensures the validity and applicability of the results obtained.

\section{Conclusion}

Treatment with Stodal provided a statistically significant decrease in the mean score of the daytime cough severity by the $7^{\text {th }}$ day of treatment, both in total population and in each age group. The statistical significance of the time-course of the cough severity from the $1^{\text {st }}$ day to the $7^{\text {th }}$ day of treatment in total population and in each age group was demonstrated:

- In Group 1 the severity of daytime cough decreased by 1.51: From 2.16 on the $1^{\text {st }}$ day of treatment to 0.65 on the $7^{\text {th }}$ day of treatment $(\mathrm{p}<0.001)$;
- In Group 2 the severity of daytime cough decreased by 1.57 : from 2.25 on the first day of treatment to 0.68 on the $7^{\text {th }}$ day of treatment $(\mathrm{p}<0.001)$;

In both groups the severity of daytime cough decreased by 1.53 : from 2.2 on the first day of treatment to 0.67 on the seventh day of treatment $(\mathrm{p}<0.001)$.

Also, the effectiveness of the study drug product was confirmed by additional data:

- The proportion of patients whose cough completely resolved or became clinically insignificant was $98 \%$. Those patients recovered. The proportion of patients whose daytime cough completely resolved ( 0 points) was $35 \%$, cough became clinically insignificant (with the score of cough severity of 1 point) in $63 \%$ of patients in both age groups combined;

- In Group 1 the severity of nocturnal cough statistically significantly decreased by 1.16: from 1.64 on the first day of treatment to 0.48 on the $7^{\text {th }}$ day of treatment $(p<0.001)$;

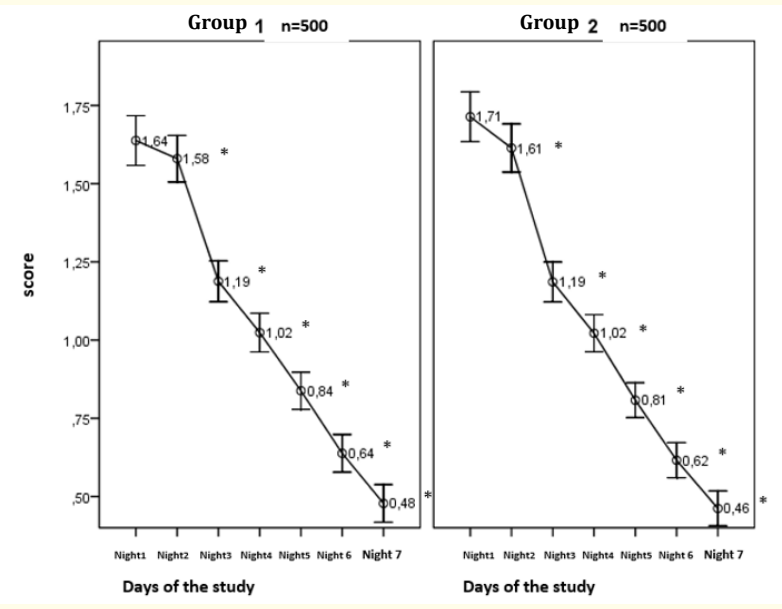

Figure 4: Dynamics of nighttime cough intensity by the groups.

$$
* \mathrm{p}<0.001 \text { vs Day } 1 .
$$

The large sample size provided statistical significance of the change of nighttime cough intensity already on the $2^{\text {nd }}$ day of treatment in both groups $(\mathrm{p}<0.001)$. A clinically significant decrease of the severity of nighttime cough (more than 1 point) occurred by the $6^{\text {th }}$ day of therapy. 


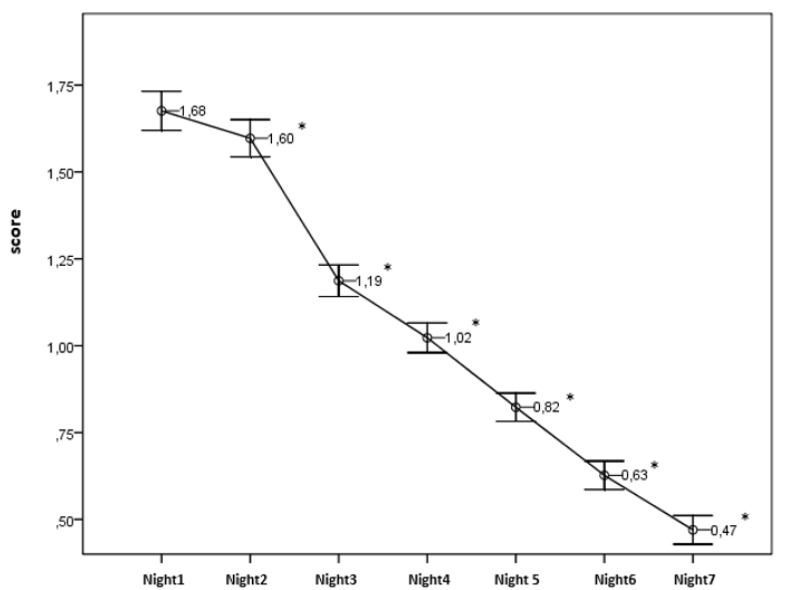

Figure 5: Nighttime cough intensity with time by groups (all

$$
\text { patients } n=1000 \text { ). }
$$$$
* \mathrm{p}<0.001 \text { vs Day } 1 .
$$

The large sample size provided statistical significance of the change of the nighttime cough intensity already on the $2^{\text {nd }}$ day of treatment $(\mathrm{p}<0.001)$. A clinically significant decrease of the severity of nighttime cough (more than 1 point) occurred by the $6^{\text {th }}$ day of the therapy.

\begin{tabular}{|l|c|c|c|c|}
\hline \multicolumn{1}{|c|}{ Groups } & & $\begin{array}{c}\text { No } \\
\text { changes }\end{array}$ & Negative & Positive \\
\hline \multirow{2}{*}{ Group 1 (n = 500) } & $\mathrm{n}$ & 62 & 2 & 436 \\
\cline { 2 - 5 } & $\%$ & 12,4 & 0,4 & 87,2 \\
\hline \multirow{2}{*}{ Group 2 (n=500) } & $\mathrm{n}$ & 34 & 2 & 464 \\
\cline { 2 - 5 } & $\%$ & 6,8 & 0,4 & 92,8 \\
\hline $\begin{array}{l}\text { All patients } \\
(\mathrm{n}=1000)\end{array}$ & $\mathrm{n}$ & 96 & 4 & 900 \\
\cline { 2 - 5 } & $\%$ & 9,6 & 0,4 & 90 \\
\hline
\end{tabular}

Table 5: Parents'/Adoptive parents' assessment of the time-course of cough severity by the $3^{\text {rd }}$ day of treatment.

\begin{tabular}{|l|c|c|c|c|}
\hline \multicolumn{1}{|c|}{ Groups } & & $\begin{array}{c}\text { No } \\
\text { changes }\end{array}$ & Negative & Positive \\
\hline \multirow{2}{*}{ Group 1 (n = 500) } & $\mathrm{n}$ & 6 & 1 & 493 \\
\cline { 2 - 5 } & $\%$ & 1,2 & 0,2 & 98,6 \\
\hline \multirow{2}{*}{ Group 2 (n = 500) } & $\mathrm{n}$ & 2 & 0 & 498 \\
\cline { 2 - 5 } & $\%$ & 0,4 & 0 & 99,6 \\
\hline $\begin{array}{l}\text { All patients } \\
(\mathrm{n}=1000)\end{array}$ & $\mathrm{n}$ & 8 & 1 & 991 \\
\cline { 2 - 5 } & $\%$ & 0,8 & 0,1 & 99,1 \\
\hline
\end{tabular}

Table 6: Parents'/Adoptive parents' assessment of the time-course of cough severity by the $7^{\text {th }}$ day of treatment.

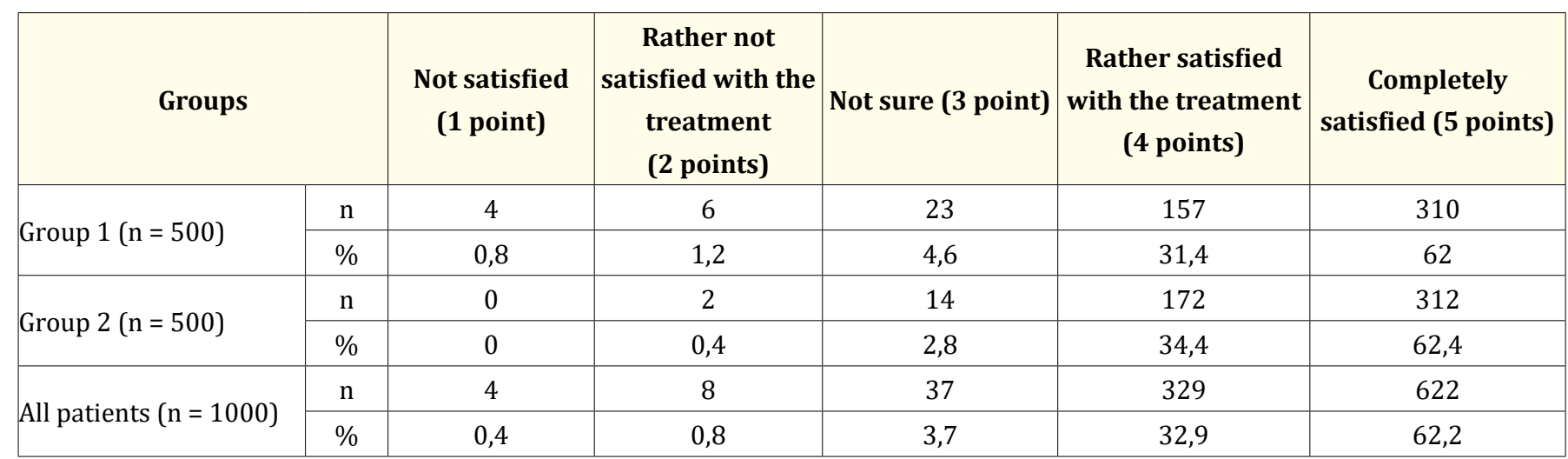

Table 7: Parents' /Adoptive parents' satisfaction with cough treatment with Stodal at the end of the treatment period.

- In Group 2 the severity of nocturnal cough statistically significantly decreased by 1.25: from 1.71 on the first day of treatment to 0.46 on the $7^{\text {th }}$ day of treatment $(p<0.001)$;
- In total population the severity of nocturnal cough statistically significantly decreased by 1.21: from 1.68 on the first day of treatment to 0.47 on the $7^{\text {th }}$ day of treatment $(\mathrm{p}<$ 0.001); 
- $951(95,1 \%)$ parents/adoptive parents positively rated the cough treatment and gave satisfaction rating with cough treatment of 4 and 5 points;

- No respiratory tract complications were reported.

Thus, Stodal reduces the duration of cough treatment during ARI to 7 days.

During the study AEs were reported in 5 patients $(0.5 \%)$. No serious AEs were reported.

The results of this study demonstrated efficiency and safety of Stodal drug product in cough treatment in children aged 2 to 7 years old with mild to moderate ARI, which allows to recommend Stodal to be included in treatment regimens beginning from the first days of the disease.

\section{Acknowledgment}

Authors express gratitude to paediatricians who took part in the study: Abdugafarova Sh.Sh. (State Budgetary Healthcare Institution, Paediatric Municipal Polyclinic No. 10 of the Moscow Health Department), Andreeva V.A. (FSBI Federal Scientific and Clinical Centre of Physical and Chemical Medicine of FMBA of Russia), Bersneva S.N. (State Budgetary Healthcare Institution, Paediatric Municipal Polyclinic No. 52 of the Moscow Health Department, Affiliated Institution No.1), Bogomolova N.M. (State Budgetary Healthcare Institution, Paediatric Municipal Polyclinic No. 105 of the Moscow Health Department, Affiliated Institution No.2), Vinogradskoy A.G. (Municipal Polyclinic No. 17, State Budgetary Healthcare Institution of the Moscow region, "The Balashikha central regional hospital" ), Vnukova N.V. (State Budgetary Healthcare Institution, Paediatric Municipal Polyclinic No. 12 of the Moscow Health Department, Affiliated Institution No.2), Gen. O.L. (State Budgetary Healthcare Institution, Paediatric Municipal Polyclinic No. 143 of the Moscow Health Department, Affiliated Institution No. 2), Dautov A.A. (State Budgetary Healthcare Institution, Paediatric Municipal Polyclinic No. 131 of the Moscow Health Department, Affiliated Institution No. 4), Efimova A.S. (Municipal Polyclinic No. 17, State Budgetary Healthcare Institution of the Moscow region, "The Balashikha central regional hospital" ), Kirusheva E.V. (State Budgetary Healthcare Institution, Paediatric Municipal Polyclinic No. 61 of the Moscow Health Department, Affiliated Institution No.1), Kozhushko M.A. (State Budgetary Healthcare Institution of the Moscow region, Paediatric Municipal Polyclinic of Podolsk), Konstantinova O.V. (State Budgetary Healthcare Institution, Paedi- atric Municipal Polyclinic No. 175 of the Moscow Health Department, Kudryavtseva Yu.B. State Budgetary Healthcare Institution, Paediatric Municipal Polyclinic No. 7 of the Moscow Health Department, Affiliated Institution No. 4), Kulavskaya V.S. (State Budgetary Healthcare Institution, Paediatric Municipal Polyclinic No. 99 of the Moscow Health Department, Affiliated Institution No. 3), Lysyakova M.Yu. (State Budgetary Healthcare Institution of the Moscow region, Paediatric Municipal Polyclinic of Vidnoye), Lyadovaya 0.0. (FSBI Federal Scientific and Clinical Centre of Physical and Chemical Medicine of FMBA of Russia), Malchugovaya Yu.V. (FSBI Federal Scientific and Clinical Centre of Physical and Chemical Medicine of FMBA of Russia), Mamedova N.D. (State Budgetary Healthcare Institution, Paediatric Municipal Polyclinic No. 143 of the Moscow Health Department, Affiliated Institution No. 3), Morozova Yu.V. (State Budgetary Healthcare Institution of the Moscow region, Nakhabino municipal hospital), Ovchinnikova S.N. (Municipal Polyclinic No. 17, State Budgetary Healthcare Institution of the Moscow region, "The Balashikha central regional hospital" ), Poloskova Y.O. (State Budgetary Healthcare Institution, Paediatric Municipal Polyclinic No. 7 of the Moscow Health Department, Affiliated Institution No. 2),, Saigushkin V.V. (State Budgetary Healthcare Institution of the Moscow region, Paediatric Municipal Polyclinic of Lobnya), Selivanova E.S. (State Budgetary Healthcare Institution, Paediatric Municipal Polyclinic No. 110 of the Moscow Health Department), Semenova N.D. (State Budgetary Healthcare Institution, paediatric Municipal Polyclinic No. 28 of the Moscow Health Department, Affiliated Institution No. 1), Silovaya O.A. (State Budgetary Healthcare Institution, Paediatric Municipal Polyclinic No. 12 of the Moscow Health Department), Stepanova I.A. (State Budgetary Healthcare Institution, Pediatric Municipal Polyclinic No. 118 of the Moscow Health Department, Affiliated Institution No. 2), Talieva F.M. (State Budgetary Healthcare Institution, Paediatric Municipal Polyclinic No. 118 of the Moscow Health Department, Affiliated Institution No. 2), Tikhonova M.N. (State Budgetary Healthcare Institution, Paediatric Municipal Polyclinic No. 110 of the Moscow Health Department), Unkina T.V. (State Budgetary Healthcare Institution, Paediatric Municipal Polyclinic No. 28 of the Moscow Health Department, Affiliated Institution No. 1), Khayrusheva A.S. (State Budgetary Healthcare Institution of the Moscow region, Paediatric Polyclinic Department No. 2, Moscow Regional Center for Maternity and Childhood Protection, Khodzhaeva Kh.Kh. (State Budgetary Healthcare Institution of the Moscow region, Paediatric Polyclinic of Dzerzhinsk municipal hospital), Chernykh E.A. (State Budgetary Healthcare Institution, Paediatric Municipal Polyclinic 
No. 105 of the Moscow Health Department, Affiliated Institution No. 3), Chuvaldina L.N. (State Budgetary Healthcare Institution, Paediatric Municipal Polyclinic No. 132 of the Moscow Health Department, Affiliated Institution No. 144), Chursina E.M. (State Budgetary Healthcare Institution, Paediatric Municipal Polyclinic No. 118 of the Moscow Health Department, Affiliated Institution No. 2), Shevchenko S.S. (State Budgetary Healthcare Institution, Paediatric Municipal Polyclinic No. 61 of the Moscow Health Department, Affiliated Institution No. 1) and Schepkina E.V. for the assistance in the statistical adjustment of the results.

\section{Author's Contribution}

All authors contributed equally to this manuscript, revised its final version and agreed for the publication.

\section{Funding}

All authors received no financial support for this manuscript.

\section{Conflict of Interests}

The authors declare that they have no conflicts of interests.

\section{Publisher's Note}

Podiatric LLC remains neutral with regard to jurisdictional claims in published materials and institutional affiliations.

Blokhin B.M. ID 0000-0003-4762-5975

Lobushkova I.P. ID 0000-0003-2690-676X

Suyundukova A.S. ID 0000-0002-4369-4300

Prokhorova A.D. ID 0000-0002-9028-7791.

\section{Bibliography}

1. Роспотребнадзор. “Сведения об инфекционных и паразитарных заболеваниях за январь-декабрь” (2018).

2. Мелехина EB., et al. “Тактика ведения детей с затяжным кашлевым синдромом после острой инфекции”. Российский вестник перинатологии и педиатрии 1.61 (2016): 110-120.

3. Блохин БМ and Лобушкова ИП. “Лечение кашля при острых респираторных заболеваниях у детей”. Доктор Ру. Педиатрия 5.160 (2019): 15-18.
4. Irwin RS., et al. "Diagnosis and management of cough executive summary ACCP evidence based clinical practice guidelines". Chest 129 (2006): 1S-23S.

5. Albert RH. "Diagnosis and treatment of acute bronchitis". American Family Physician 82 (2010): 1345-1350.

6. Morice AH., et al. "Recommendations for the management of cough in adults". Thorax 61 (2006): i1-24.

7. Jones BF and Stewart MA. "Duration of cough in acute upper respiratory tract infections". American Family Physician 31 (2002): 971-973.

8. Niimi A., et al. "Impaired cough reflex in patients with recurrent pneumonia". Thorax 58 (2003): 152-153.

9. Cole AM., et al. "Innate antimicrobial activity of nasal secretions". Infection and Immunity 67 (1999): 3267-3275.

10. Knowles MR and Boucher RC. "Mucus clearance as a primary innate defense mechanism for mammalian airways". Journal of Clinical Investigation 109 (2002): 571-577.

11. Wanner A., et al. "Mucociliary clearance in the airways". American Journal of Respiratory and Critical Care Medicine 154 (1996): 1868-1902.

12. Canning BJ. "Anatomy and neurophysiology of the cough reflex ACCP evidence based clinical practice guidelines". Chest 129 (2006): 33S-47S.

13. Учайкин ВФ., ред. Диагностика, лечение и профилактика гриппа и острых респираторных заболеваний у детей: пособие для врачей. М., (2001).

14. Мелехина EB., et al. “Тактика ведения детей с затяжным кашлевым синдромом после перенесенного острого респираторного заболевания". Взгляд врача педиатраинфекциониста. Журнал Международной Медицины. Педиатрия/ Неонатология 6.17 (2015): 83-88.

15. Локшина ЭЭ., et al. “Опыт применения натуропатического препарата Стодаль у детей с острыми респираторными заболеваниями". Педиатрия. Журнал им. Г.Н. Сперанского. 95.3 (2016): 158-163. 
16. Zanasi A., et al. "Homeopathic medicine for acute caught in upper respiratory tract infections and acute bronchitis: a randomized, double-blind, placebo-controlled trial". Pulmonary Pharmacology and Therapeutics 27.1 (2014): 102-108.

17. Геппе НA., et al. “Новое в терапии кашля при острых респираторных заболеваниях в педиатрической практике”. Лечащий врач 9 (2017): 86-90.

18. Короид НВ., et al. "Внебольничные пневмонии у детей: диагностика и лечение. Русский медицинский журнал". Мать и дитя 22 (2011): 1365-1370.

19. Захарова ИН., et al. “Эффективность препарата Стодаль при кашле у детей на фоне острой респираторной инфекции. Consilium Medicum”. Приложение Педиатрия 1 (2019): 37-43.

20. Селькова ЕП., et al. “Тактика лечения непродуктивного кашля у детей при заболеваниях респираторного тракта вирусной этиологии". Лечащий врач 8 (2013): 84-88.

21. Likert R. "A Technique for the Measurement of Attitudes. New York: The Science Press, 1932". Archives of Psychology 140 (1932): 1-55.

22. “Стандартная операционная процедура мониторинга эффективности и безопасности лекарственных препаратов в медицинскихорганизацияхгосударственной системы здравоохранения города Москвы для врачей общей практики и среднего медицинского персонала". Методические рекомендации № 25. М.В. Журавлева, ред. М.: Департамент здравоохранения города Москвы (2019).

\section{Volume 5 Issue 7 July 2021}

(C) All rights are reserved by BM Blokhin., et al. 